Brit. J. vener. Dis. (1956), 32, 242.

\title{
ROLE OF TREPONEMA REITER IN MODERN SEROLOGY OF SYPHILIS*
}

\author{
BY \\ H. G. S. RUGE \\ From the Department of Tropical Medicine, Kiel University, Germany
}

Wassermann and Ficker (1922) succeeded in isolating seven virulent strains of Treponema pallidum from the serum from eighty to ninety primary chancres. One strain, $\mathbf{B}_{36}$, was kept and cultivated in an anaerobic fluid medium consisting of diluted horse serum to which a piece of boiled liver was added, and at that time, the strain proved virulent for rabbits after a series of subcultures (Reiter).

It appears that this strain was the first to be successfully cultivated. Previously, Noguchi (1911a, b, 1912) had claimed to have been able to isolate and keep $T$. pallidum, but his findings could not be confirmed. The same fate happened to the discovery of Nakano $(1912,1913)$ who published several papers in 1913 in which he claimed that he had been able to obtain subcultures. $\mathrm{He}$ and Noguchi produced from their cultures the so-called "Luetin" with which they could obtain positive skin reactions in syphilitic patients.

In 1922 Reiter infected rabbits with a number of cultivated syphilis strains of which strain $B_{36}$ was one. In the following years he published a series of papers which were devoted to work on this strain (Reiter, 1924, 1925, 1926a, b, 1929). From that time it has been known as Treponema Reiter. Klopstock (1926) was the first to obtain positive serum reactions in syphilitic patients with a dense alcoholic suspension of this strain. He states clearly in his first paper that this strain came from Ficker and had already been cultivated for some years. In the meantime the strain had completely lost its virulence and it was no longer possible to transmit it successfully to rabbits (Króo and Schulze, 1929; Plaut and Kassowitz, 1930). Later Gaehtgens (1929, 1937) experimented with the strain and in long systematic investigations he produced a useful antigen called Palligen. This antigen consisted of a concentrated emulsion of purified Treponema Reiter which were suspended in carbolized saline.

According to about forty papers published between 1929 and 1949 in Germany and abroad,

* Received for publication July 6, 1956. including Beck (1939) in England, Eagle and Hogan (1940) in the U.S.A., and Muster (1942) and Lauber (1949) in Switzerland, the test was regarded as specific. The rate of biologic false positives was about 1 per cent. These papers were critically summarized by Gaehtgens $(1929,1937)$.

Jahnel (1934) reported that he had investigated all available strains of the so-called Treponema pallidum. By morphological and tinctorial studies only, he reached the conclusion that not all these strains were Treponema pallidum, but possibly belonged to the group of Spirochaeta gracilis, a saprophytic spirochaete which was found in the genital region. According to Bergey (1948), there are three genera in the family of treponemataceae: Borrellia (Swellengrebel, 1907), Treponema (Schaudinn, 1905), and Leptospira (Noguchi, 1917). To the genus Treponema belong eight species: $T$. pallidum, pertenue, carateum (pinta), cuniculi (rabbit), microdentium (normal oral cavity), genitale (from human genitalia), calligyrum (from smegma), and mucosum (which is reported as having pyogenic properties). This classification appears contradictory-at least to a certain extent-according to the results obtained by Gaehtgens (1929, 1937), Beck (1939), Koch (1940), and Eagle and Hogan (1940) in absorption and complement-fixation tests. Thus it would seem improbable that antigens of the saprophytic $S p$. gracilis ( $T$. genitale and calligyrum, respectively) would exercise such a specific influence on syphilitic sera as the genuine Reiter antigen. On the contrary, Rose and Morton (1952) who work with cultivated Reiter, Nicols (avirulent variety), and Kazan strains, respectively, emphasized that the morphological differences were due to the respective media, and it was possible to preserve the characteristic helicoidal morphology of these strains in special media.

During the second world war the Reiter strain was lost in Germany and it was not possible to manufacture a new antigen until 1951 (Fühner, 1952). In the meantime, in particular Italian and later German and French scientists were elucidating the antigenic structure and properties of Treponema 
Reiter. It was still possible to obtain a positive serology in syphilitic sera and also in rabbits that had previously been injected with heavy suspensions of living or killed treponemata. Moreover, newlyperformed absorption tests on human syphilitic sera-such trials had already been done by Gaehtgens in 1929, and confirmed by Beck (1939) and Eagle and Hogan (1940), but contested by Kolmer, Kast, and Lynch (1941)-proved that Treponema Reiter antigens were different from the generally used lipid antigens and were probably linked to specific globulin containing antibodies in syphilitic sera, and to a much lesser degree to polysaccharide and lipid (D'Alessandro, 1946; D'Alessandro and Dardanoni, 1953; D'Alessandro, Oddo, Comes, and Dardanoni, 1949; D'Alessandro and Puccinelli, 1944; Puccinelli, 1951, 1952; Dardanoni, 1955; Dardanoni and Zaffiro, 1955; Oddo, 1947; Oddo and Dardanoni, 1947; Oddo and D’Ambrosio, 1947; Potel, 1954, 1955; Hippius, 1954; Fromm, 1954a, b, 1955a, b).

It was discovered that Treponema Reiter consisted of three different antigens:

(a) Thermolabile protein antigen;

(b) Thermostable polysaccharide antigen;

(c) Lipid antigen (similar to that found in the usual antigens).

On the other hand, positive TPI tests employing virulent treponemata were obtained with the sera from patients suffering with framboesia (yaws) or pinta, and immobilization was also obtained with the serum of rabbits infected with Treponema cuniculi; but no immobilization occurred when the rabbits were injected with living or killed Treponema Reiter (Nelson and Diesendruck, 1951; Kahn, Nelson, and Turner, 1951; Edmundson, Lopez, Rico, and Olansky, 1953).

Furthermore, intradermal inoculation experiments by Medina (1954) with three strains of Treponema pertenue on healthy, syphilitic, and pinta patients gave the following interesting results; an infection was always obtained in healthy people. The infection developed also in syphilitic and pinta patients who had been adequately treated. If such patients were not sufficiently treated (latent cases), no infection took place. This suggests that after sufficient treatment immunity no longer exists against a new infection by a related treponema.

These findings enlarge to a certain extent Turner's re-inoculation experiments on infected syphilitic rabbits.

The different behaviour of these treponema strains led Hoffmann $(1953,1956)$ to the conclusion that probably one kind of treponema had originally existed and that this had split off in the past after the discovery of America and the introduction to Europe of framboesia which developed into syphilis through climatic conditions and sexual debaucheries and divided into four antigenically, partially different species, as was demonstrated by TPI crossreaction (Nelson and Diesendruck, 1951; Kahn, Nelson, and Turner, 1951).

Therefore, Treponema Reiter, Nicols (avirulent variety), and Kazan may also be regarded as at least group specific, although they have completely lost their virulence. ${ }^{*}$ This means that in practically all cases of untreated treponematosis which last for some weeks, positive serum reactions with modern and improved Reiter antigens can be expected (Fühner and Gaehtgens, 1954; Fromm, 1954a, b, $1955 \mathrm{a}, \mathrm{b})$. This assumption is supported by the fact that good results have been observed with the new Palligen (R). $\dagger$ The rate of biologic false positives is low, and its specificity and sensitivity are equal or even superior to those of the Cardiolipin Kolmer. Since the Palligen reaction is concerned with the globulin antibodies in the serum and to a much less degree with lipid antibodies, complete agreement with the usual battery of STS cannot be expected. In spite of this, good agreement is generally found (Fegeler and Knauer, 1955; Henze, 1954; Gropper, 1955; Joest, 1955; Schlirf and Seidenstücker, 1954). Thus the reaction may serve as an additional test to complete the serological pattern (Fühner, 1952). Sometimes, an isolated, repeatedly positive, Pallida reaction may give a valuable hint, if syphilis is still present, and in this way the labour of a TPI test may be saved (Fühner, 1952; Bénazet, Brottes, Thivolet, and Sohier, 1954). In this connexion the paper of Moser (1955), comparing Palligen with TPI and a battery of STS may also be mentioned.

\section{RESULTS}

Personal experience of 707 reacting sera, which were checked at random with TPI tests and a battery of STS, indicate that there is a good agreement with the other tests and a low percentage of biologic false positives (Table, overleaf).

No difficulties were encountered regarding the narrow safety limit of the Reiter antigen-as described by Gastinel, Vaisman, and Hamelin (1956) if the technique recommended by Gaehtgens was closely followed. A quantitative titration is also possible. Since this reaction is based upon premises other than the lipid reactions, the titre will often differ from that of a Kolmer Wassermann, or a VDRL titre. Generally the titres will not exceed

* For instance, Gelperin (1951) was unable to protect rabbits against syphilis by immunization with Reiter's spirochaetae.

$t$ (R) Pallida-Antigen Promonta, Hamburg 26. 
TABLE

707 REACTING SERA

\begin{tabular}{|c|c|c|c|c|c|c|c|c|}
\hline \multirow{2}{*}{ Type } & \multicolumn{2}{|c|}{ Specific } & \multicolumn{2}{|c|}{$\begin{array}{l}\text { Biologic } \\
\text { False } \\
\text { Positive }\end{array}$} & \multicolumn{2}{|c|}{$\begin{array}{l}\text { Negative } \\
\text { Net }\end{array}$} & \multicolumn{2}{|c|}{ Total } \\
\hline & $\begin{array}{c}\text { Pos/ } \\
\text { doubtful }\end{array}$ & \begin{tabular}{|c|} 
Per \\
cent.
\end{tabular} & $\begin{array}{c}\text { Pos/ } \\
\text { doubtful }\end{array}$ & \begin{tabular}{|c|} 
Per \\
cent.
\end{tabular} & Abs. & $\begin{array}{c}\text { Per } \\
\text { cent. }\end{array}$ & Abs. & $\begin{array}{l}\text { Per } \\
\text { cent. }\end{array}$ \\
\hline $\begin{array}{l}\text { Meinicke } \\
\text { Clarification }\end{array}$ & 476 & $67 \cdot 3$ & $2^{*}$ & $0 \cdot 3$ & 231 & $\mid 32 \cdot 7$ & 707 & 100 \\
\hline $\begin{array}{l}\text { CMT } \\
\text { (VDRL) }\end{array}$ & 647 & $91 \cdot 5$ & $16 \ddagger$ & $2 \cdot 2$ & 60 & $8 \cdot 5$ & 707 & 100 \\
\hline $\mathbf{W} / \mathbf{R}$ Original & 170 & $23 \cdot 7$ & $2+$ & $0 \cdot 3$ & 535 & $76 \cdot 0$ & 707 & 100 \\
\hline $\begin{array}{l}\text { W/R- } \\
\text { Cardiolipin }\end{array}$ & 309 & $43 \cdot 6$ & $2 f$ & 0.3 & 396 & $56 \cdot 1$ & 707 & 100 \\
\hline $\begin{array}{r}\text { W/R-Kolmer } \\
\text { Cardiolipin }\end{array}$ & 318 & $76 \cdot 4$ & $2 *+$ & 0.5 & 96 & $23 \cdot 1$ & 416 & 100 \\
\hline Palligen & 5698 & $80 \cdot 3$ & $2 *$ & $0 \cdot 3$ & 137 & $19 \cdot 4$ & 707 & 100 \\
\hline
\end{tabular}

$1: 128$. The proportion among the three reactions (i.e. VDRL : Pallida : Kolmer Wassermann) is about $1: 2 \cdot 5: 10$, found in 351 and 100 comparative titrations, respectively. Anticomplementary sera are no more frequently observed than in the other complement-fixation tests. Besides, anticomplementary properties of serum can easily be removed with ordinary kaolin (Ruge, 1956). It may be added that Gastinel, Vaisman, and Hamelin (1956) have recently reported similar good results with Palligen, an Italian antigen, and an antigen prepared in the Pasteur Institute, Paris. In addition, 511 parallel tests using the TPI test have been compared. If the specificity of TPI is taken as 100 per cent., the biologic false positive rate with Palligen was 0.75 per cent., whereas with the lipid reactions this rate rose to 6.65 per cent. Similar findings have previously been published by other French authors (Bénazet and others, 1954; Mutermilch, and Delaville, 1955; Pautrizel, Szersnovicz, and Gimenez, 1953; Pautrizel, Szersnovicz, and Rollet, 1954; Hardy, Bornand, and Durel, 1955).

Furthermore, studies have been done on the antigenic properties of the albumin fraction (ATPS) of Treponema Reiter. Dardanoni (1955) infected a series of 35 rabbits and examined the serum after 6-28 days. He encountered positive reactions with the usual lipid antigens, ATPS, and weakly-positive TPI tests. ATPS was regarded as more sensitive than the classical tests. Similar experiments were performed by Pisu and Mastromatteo (1955) on 2,780 human sera using a battery of STS, ATPS test, and the Treponina test (a suspension of Treponema Reiter). The authors conclude that here also ATPS was more specific than Treponina and presented no biologic false positives, although
Treponina gave many more positive isolated and combined (Wassermann and/or flocculation tests positive) specific reactions. But some biologic false positives were met with in these reactions. Apparently, this matter needs further careful study.

\section{Summary AND Conclusions}

Research work done during the past decade on Treponema Reiter has again indicated its value at least as a group-specific antigen in the serodiagnosis of syphilis. It has been proved that this antigen is mostly linked to the albumin-containing, and to a lesser degree to the lipid, antibodies in human syphilitic serum. This fact has newly been confirmed by numerous absorption experiments mostly performed by Italian, French, and German scientists.

Since this complement-fixation test gives a different pattern from the complement-fixation tests performed with cardiolipin and co-antigens, a complete agreement between these two forms of complement-fixation and flocculation tests cannot therefore be expected.

As a group-specific antigen the Reiter antigen will have fewer biological false positives presumably than the lipid antigens; and thus permanently isolated positive reactions may justify the assumption of a specific infection. The new Treponema Reiter antigen and its albumin fractions will certainly play an important role in the modern sero-diagnosis of syphilis as it emphasizes and supports the specificity of the classical (lipid) tests performed and thus completes the sero-diagnostic pattern.

\section{REFERENCES}

Beck, A. (1939). J. Hvg. (Lond.), 39, 298.

Bénezet, F., Brottes, H., Thivolet, J., and Sohier, R. (1954). Ann. Inst. Pasteur, 86, 674.

Bergey, D. H. (1948). "Manual of Determinative Bacteriology", 6th ed., p. 1058. Baillière, Tindall and Cox, London.

D'Alessandro, G. (1946). Boll. Ist. sieroter. milan., 25, 138.

D Alessandro, Dardanoni, L. (1953). Amer. J. Syph., 37, 137.

-, Oddo, F., Comes, R., and Dardanoni, L. (1949). Riv. Ist. sieroter. ital., 24, Sez. II, 134.

- and Puccinelli, V.'(1944). G. Med., 1, 68.

Dardanoni, L. (1955). Riv. Ist. seiroter. ital., 30, 105, 414.

- and Zaffiro, P. (1953). Minerva med. (Torino), 44, II, 1500

Eagle, H., and Hogan, R. B. (1940). J. exp. Med., 71, 215.

Edmundson, W. F., Lopez Rico, A., and Olansky, S. (1953). Amer. J. Syph., 37, 201 .

Fegeler, F., and Knauer, I. (1955). Z. Haut-u. Geschlkr., 18, 76

Fromm, G. (1954a). Arztl. Wochenschr., 9, 639.

(1954b). Hautarzt, 5, 543.

(1955a). Ibid., 6, 20.

(1955b). Z. Hyg. Infektkr., 141, 469.

Fühner, F. (1952). Arztl. Wschr., 7, 644.

- and Gaehtgens, W. (1954). 'Z. Hyg. Infektkr., 138, 573.

Gaehtgens, W. (1929). Ztschr. ImmunForsch., 63, 398.

Gaehtgens, W. (1929). Ztschr. ImmunForsch., 63,

—(1937). Arch. Derm. Syph. (Berlin), 176, 42.

Gastinel, P., Vaisman, A., and Hamelin, A. (1956). Ann. Inst. Pasteur, 90, 249.

Gelperin, -. (1951). Aimer. J. syph., 35, 1.

Hardy, N., Bornand, G., and Durel, P. (1955). Bull. Soc. frans. Derm. Syph., 62, 55. 
Henze, S. (1954). Medizinische, 1949.

Hippius, H. (1954). Z. ImmunForsch., 111, 491

Hoffmann, E. (1953). Derm. Wschr., 127, 267.

(1956). Schweiz. med. Wschr., 86, 281.

Jahnel, F. (1934). Klin. Wschr., 13, 550.

Joest, W. (1955). Z. Haut-u. Geschlkr., 18, 300.

Kahn, A. S., Nelson, R. A. Jr., and Turner, T. B. (1951). Amer. J. Hyg., 53, 296.

Klopstock, F. (1926). Dtsch. med. Wschr., 52, 226, 1460.

Koch, F. (1940). Zbl. Bakt., I. Abt. Orig., 145, 338.

Kolmer, J. A., Kast, C. C., and Lynch, E. R. (1941). Amer. J. Syph.,

Króo, F. O., and Schulze, H. (1929). Kiln. Wschr., 8, 1203.

Lauber, K. (1949). Praxiz (Bern), 38, 50.

Medina, R. (1954). Arch. venez. Patol. trop., 2, 51.

Moser, L. (1955). Zbl. Bakt., I. Abt. Orig., 163, 369.

Muster, I. (1942). Dermatologica (Basel), 86, 351.

Mutermilch, S., and Delaville, M. (1955). Ann. Biol. clin., 13, 398.

Nakano, H. (1912). Dtsch. med. Wschr., 38, 1333.

(1913). Arch. Derm. Syph. (Berlin), 116, 265.

Nelson, R. A. Jr., and Diesendruck, J. A. (1951). J. Immunol., 66, 667.

Noguchi, H. (1911a). J. exper. Med., 14, 99.

(1911b). Münch. med. Wschr., 58, 1550

(1912). J. Amer. med. Ass., 58, 1163.

(1917). J. exp. Med., 25, 755.
Oddo, F. G. (1947). Boll. Ist. sieroter, milan., 26, 9.

and D'Ambrosio, G. (1947). Boll. Soc. ital. Biol. sper., 23, 883.

_- , and Dardanoni, L. (1947). Ibid., 23, 1090

Pautrizel, R., Szersnovicz, F., and Gimenez, A. (1953). Quoted by Hardy and others, 1955

-, and Rollet, M. (1954). Bull. Soc. Pharm., Bordeaux, 92, 141 .

Plaut, F., and Kassowitz, H. (1930). Klin. Wschr., 9, 1396.

Pisu, I. R., and Mastromatteo, M. (1955). Riv. Ist. sieroter, ital., 30, 123.

Potel, J. (1954). Prophylaxe, 1, No. 5.

Puccinelli, V. A. (1951). Amer. J. Syph., 35, 340.

(1952). Atti XXXVI Congr. Soc. ital. Derm. Syph., 2, 5.

Reiter, H. (1924). Zbl. Bakt., I. Abt. Orig., 92, 534.

(1925). Dtsche. med. Wschr., 51, 303.

(1926a). Klin. Wschr., 5, 444.

(1926b). Derm. Wschr., 83, 1199.

(1929). Ibid., 89, 1401.

Rose, N. R., and Morton, H. E. (1952). Amer. H. Syph., 36, 1.

Ruge, H. G. S. (1956). Amer. J. clin. Path., 26, 98

Schaudinn, F. (1905). D. Psch. med. Wschr., 31, 1728.

Schlirf, K., and Seidenstücker, H. (1954). Z. Hyg. Infkrkr., 140, 409.

Swellengrebel, N. H. (1907). Ann. Inst. Pasteur, 21, 582.

Turner, T. B. (1939). J. exper. Med., 69, 867.

Wassermann, A., and Ficker, M. (1922). Klin. Wschr.. 1. 1101. 